Vol.8 No.1, pp.35-49, March 2020

Published by ECRTD UK

ISSN 2054-0930 (Print), ISSN 2054-0949 (Online)

\title{
SUPPLIER COLLABORATIVE ARRANGEMENTS, SUPPLIER GENERATIVE INFLUENCE, SELF-ORGANIZATION \& BID RIGGING IN PUBLIC PROCUREMENT
}

\author{
Phiona Nanfuka ${ }^{1}$, Samuel Pule ${ }^{2 * *}$, Patrick W. Mafumbo ${ }^{3}$ \\ Lecturer, Faculty of Business \& Management, Victoria University Uganda ${ }^{1,2,3}$ \\ Victoria Towers, Plot 1 -13 Jinja Road, P.O. Box 30866, Kampala Uganda
}

\begin{abstract}
This article examines the relationship between supplier collaborative arrangements, supplier generative influence, self-organization and bid rigging in Uganda's Public Procurement. A sample of 120 Procurement and Disposal Entities (PDE's) and 317 supplier companies were selected with an average response rate of 76\%. Data was analyzed using Statistical Package for Social Scientists (SPSS). Results showed a positive and significant relationship between supplier collaborative arrangements, supplier generative influence, selforganization and bid rigging. Similarly, results of the regression model revealed that supplier collaborative arrangements, supplier generative influence and self-organization are significant predictors of bid rigging in Ugandan Public Procurement. We recommend that in order for PDE's in Uganda to reduce bid rigging special consideration should be directed at managing and monitoring suppliers' behavior from the time of bidding until the contact has been fully executed.
\end{abstract} KEYWORDS: supplier collaborative arrangements, supplier generative influence, selforganization, bid rigging

\section{INTRODUCTION}

According to the World Bank (2015), Public Procurement represents $70 \%$ of the government expenditure in Uganda. The high percentage shows how public procurement is vulnerable to procurement fraudulent practices like bid rigging which increase the expenditure even higher. Bid rigging is an anti-competitive arrangement where competing firms determine the bidding process outcome choosing a member who will submit the winning bid and who will not (Amanda, 2014). The bidders agree to eliminate competition to deny the buyer a competitive price. Bid rigging is comprised of anti-competitive forms like market allocation, bid suppression, cover pricing, bid rotation and sub-contracting that suppliers engage into to manipulate the public procurement process hence impacting on the government expenditure negatively (Bael \& Bellis (2017).

Bid rigging is harmful to the economy and the public as it increases the government overall expenditure if there is no effective competition (Ilango, 2014). Bid rigging is detected when bids received at the same time contain similar information; expected bidders fail to submit bids and the successful bidder later subcontracts work to another supplier (Transparency International, 2016). What bidders do is to resort to conspiracies amongst themselves, collaboration, cooperation, coordination; combination and agreements through which they perform bid rigging. Sectors vulnerable to bid rigging are those sectors with few economic operators and absence of alternatives 
Vol.8 No.1, pp.35-49, March 2020

Published by ECRTD UK

ISSN 2054-0930 (Print), ISSN 2054-0949 (Online)

to the services and products for example construction contracts, pharmaceutical contracts etc. (OECD, 2012). A competitive bidding process is functional when prices are set honestly and independently without conspiracies by the competitors to cheat the customer (Bajari \& Ye., 2001). According to the PPDA Act (2003) section 93 code of conduct, suppliers are required to sign the code declaring syntax to be compliant with PPDA Act and Regulation and as well states the penalties of such offences but however bid rigging still exists.

Despite the PPDA Act, Ugandan Procuring and Disposing Entities are still facing challenges of bid rigging. According to the PPDA Audit Report (2010), Sinohydro Corporation Limited filed for an administrative review to UNRA on grounds that its bid had been rejected for the award of the contract for the rehabilitation/ strengthening of the Malaba/ Busia road 2008. The Report further indicated that Sinohydro had misused the Instructions to Bidders clause 62 on joint venture or subcontracting. Subcontracting by the potential bidders was supposed to be indicated as a requirement while filling the information form in case of joint venture but Sinohydro filled the form and it clearly indicated that joint venture was not applicable in their case. However, it was later noted in the bid of Sinohydro that for reasons of competitiveness and offering the client comprehensive service. Sinohydro had decided to enter into a collaborative arrangement with Gauff Ingenieure to provide engineering design services for the project. Suppliers network, collaborate, share information and adapt to the environment in order to win bids in the complex competitive market. When suppliers network they determine the contract price contrary to the prevailing market price (Transparency International, 2016). Suppliers interacting before bidding process lead to uncompetitive bidding (OECD, 2016). The intention of subcontracting and not declaring it to the authority shows an act of fraud by Sinohydro.

\section{Statement of the Problem}

According to PPDA Act (2003) amended in (2014) Public procurement is based on the principles of competition, value for money and fairness so that all stakeholders gain from it. The intention for value for money can easily be achieved if there is realistic competition amongst suppliers. However, several PPDA Audit reports including among others, the 2017 Audit Report that shows anti-competitive practices by suppliers who coordinate, collaborate, conspire, and cooperate and form agreements which they use to manipulate the public procurement and disposal process and deny the buyer a competitive price. Bid rigging causes heavy financial loss to the government of Uganda every year (Kimera, 2006). Such bid rigging behavior can be attributed to supplier collaborative arrangements, supplier generative influence and self-organization. The paper therefore aims at examining why in spite the PPDA Law and other anti-graft frameworks, bid rigging has continued to manifest itself within the public procurement systems of Uganda.

\section{Purpose of the Study}

To examine the relationship between, supplier collaborative arrangements, supply generative influence, self-organizing and bid rigging in Uganda's public sector procurement system. Specifically, the study analyzed; (1) the relationship between supplier collaborative arrangements and bid rigging, (2) the relationship between supplier generative influence and bid rigging, and 
Vol.8 No.1, pp.35-49, March 2020

Published by ECRTD UK

ISSN 2054-0930 (Print), ISSN 2054-0949 (Online)

lastly, (3) the relationship between self-organization and bid rigging among public sector organizations.

\section{REVIEW RELATED STUDIES}

\section{Supplier Collaborative Arrangements and Bid Rigging}

Suppliers have entered into collaborative arrangements as a way of adapting to changes in the environment (Mehrjerdi, Y.Z., 2009). These collaborative arrangements help them assist each other in due course of their relationships. Although, Todeva \& Kneke, (2005) argue that supplier collaborative arrangements may be both negative and positive but in bid rigging the impact of collaboration has negative out comes to the public. It affects quality performance among suppliers and usually leads to buyers getting cheated (Bael \& Bellis (2017). However, while suppliers come up with order on how to share information and joint decision making, they are trying to gather all possible information necessary for them to bid effectively without making the procurement officers suspicious of their actions (Aburto \& Weber, 2007). Supplier collaboration reduces the risk of losing a contract to a competitor and that is why potential bidders collude to defeat competition bringing about bid rigging. Through collaborative arrangements suppliers work together in order to manipulate the procurement process therefore play a big role in determining who the winner of the tender will be (OECD, 2016).

Supplier collaborative arrangements are a search for competitive advantage while avoiding market uncertainties however it may not guarantee that they will win the contract but chances are high that they will come out victorious (CUT CCIER, 2008). Through collaborative arrangements suppliers govern relationships, safe guard partner interests, resource contributions such as technology and division of rewards jointly (Różowicz, K. 2017). Suppliers agree to remain legally independent, share managerial tasks as tasked to accomplish. This brings benefits to the partners such as defeating competition because if this was done individually then winning contracts would be a challenge (Simatupang \& Sridharan, 2002). When suppliers collude they are able to bring resources together, safe guard each other's interests, and after share profits when one of them wins a tender. Supplier collaborative arrangements require trust as confidence in one another (Ring \& Ven, 1994). The social psychological explanation of trust includes commitment, forbearance, cooperation, coordination, full filling obligations as required. Potential bidders in there arrangements agree to eliminate competition by deciding a member who will submit the winning bid, conspire to deny relevant information to the buyer, agree not to reduce prices or give discounts to the buyer, mark geographical locations as a way of eliminating outside bidders (OECD, 2012).

\section{Supplier Generative Influence and Bid Rigging}

Generative influence is the process and or capacity which help people see old things in new ways (Eriksons, 1993). It gives suppliers a high bargaining power. Business may succeed or fail because of the outcomes of complex interactions in the changing environment. Generative influence is a construct in human development (Erikson, 1993; Aubin, 2004). It plays a role in influencing the next generation. Generative influence facilitates the transfer of useful knowledge and other business practices. Suppliers learn from challenging situations by being innovative to remain 
European Journal of Logistics, Purchasing and Supply Chain Management

Vol.8 No.1, pp.35-49, March 2020

Published by ECRTD UK

ISSN 2054-0930 (Print), ISSN 2054-0949 (Online)

competitive. Generative influence encourages sustainability as it promotes continuity and adaptive changes in any organization.

Learning enables suppliers to co-create and learn together. Learning is more than just exchange of information but rather co-learning. In simple bid rigging is complex, interconnected and evolving. Different suppliers hold knowledge or skills those others may not have. This calls for co-learning. This helps to support and enable suppliers to self-organize and achieve their intended goals. Suppliers' role is to facilitate the conditions of self-organizing so that bid rigging can take place. Bid riggers form networks in order to achieve a common goal therefore networking leads to bid rigging. Despite this however, networking in business is generally important because it helps firms integrate and develop relationships through which they can not only lower transactional costs of businesses but also enable firms access new markets (North, et al., 2017).

\section{Self-Organizing and Bid Rigging}

Self-organizing is characterized by systemness which means that self-organization takes place in a system, forms interactions, relationships that adapt to its environment (Levy, 1994). While systems are self-organizing there are limits that influence the behavior of the system like technology (Ashby, 2004). This causes a system to enter a phase of instability. The system then intensifies so as to initiate in order to form order. Feedback will then occur in a self-organizing system. The causes and effects of self-organizing are nonlinear as a small change may lead to a big effect and a big cause may lead to a small effect (Kauffman, 1993). However it's also possible for a small cause to lead to a small effect and a big cause to lead to a big effect. This leads to transition from stability to instability. The system then selects which alternative paths of development to take. Self-organizing takes place in an open system which can accommodate irreversible and reversal energy (Ashby, 2004).

Fuchs, et al., (2002) indicates that emergency is the generation of knowledge when individuals come together to share ideas. This arises from interactions. The ideas and knowledge can be improved to come up with new ideas and knowledge always. Adaptation is the learning of new ideas and knowledge and always improving it. Learning is understanding (connectivity, interdependence, emergency and self-organization). Understanding these characteristics helps potential bidders to collude effectively. According to Goldestein (1999) when two or more parties come together to solve the communication problem so as to accomplish a task that would not have been possible if this party was alone because of insufficient information. Communication under complexity analyses the amount of information needed by all parties to perform an intended task which in this case is bid rigging.

\section{METHODOLOGY}

\section{Research Design}

A quantitative approach was adopted which employed a descriptive and analytical research design to examine whether supplier collaborative arrangements, Supplier generative influence and Selforganization influenced bid rigging. Correlation design was adopted to explain the relationships 
European Journal of Logistics, Purchasing and Supply Chain Management

Vol.8 No.1, pp.35-49, March 2020

Published by ECRTD UK

ISSN 2054-0930 (Print), ISSN 2054-0949 (Online)

between the variables of the study and a regression design was adopted to determine the extent to which the independent variables explained bid rigging (the dependent variable).

\section{Study Population and Sample Size}

The study population consisted of 176 Procurement and Disposing Entities (PDEs) and 1,765 construction firms in Kampala. Using the Krejcie \& Morgan (1970) sampling method the researcher arrived at a sample size of 120 PDEs and 317 construction firms so as to gather data on the research study variables. The unit of analysis were PDEs and construction firms.

Table 1: Population and Sample Size

\begin{tabular}{|l|c|c|}
\hline Units of Analysis & Population & Sample Size \\
\hline No of PDEs (Kampala) & $\mathbf{1 7 6}$ & $\mathbf{1 2 0}$ \\
\hline No of Suppliers (Construction Firms) & $\mathbf{1 7 6 5}$ & $\mathbf{3 1 7}$ \\
\hline
\end{tabular}

Source: Primary Date (2017) Sampled using the Krejcie \& Morgan (1970) Sampling Method

\section{Sampling Design and Procedure}

The researcher used simple random sampling and Stratified sampling to get the PDEs. Construction firms were obtained from the stratified PPDA list since they appeared under several strata. In each stratum, PDEs and Construction firms were arranged in alphabetical order and randomly selected to get the sample (120 and 317 firms and respondents from each firm) respondents. This guaranteed the desired distribution among the selected subgroups of the population and reduced bias when selecting construction firms.

\section{Data Collection Methods}

Self- administered questionnaires were used to obtain quantitative data respectively in primary sources in order to get valid responses because it allowed the respondents to fill them at their convenience. The questionnaires were designed following the objectives of the study. The questions in the questionnaire were anchored on a six (6) point Likert Scale ranging from $6=$ strongly agree, 5=agree, 4=somewhat agree, 3=somewhat disagree, $2=$ disagree, 1=strongly disagree. Consisted 3 sections; Section A was composed of the background information for the respondents; B consisted of the background information of the organization. $\mathrm{C}$ comprised of the perception of respondents towards bid rigging. 
European Journal of Logistics, Purchasing and Supply Chain Management

Vol.8 No.1, pp.35-49, March 2020

Published by ECRTD UK

ISSN 2054-0930 (Print), ISSN 2054-0949 (Online)

Measurement of Variables

Table 2: Measurement of Variables

\begin{tabular}{|l|l|l|}
\hline Variable & Measurement Items & Authors \\
\hline $\begin{array}{l}\text { Supplier Collaborative } \\
\text { Arrangements }\end{array}$ & $\begin{array}{l}\text { Information sharing, joint } \\
\text { decision making \& incentive } \\
\text { alignment }\end{array}$ & $\begin{array}{l}\text { Bael \& Bellis (2017), } \\
\text { Simatupang \& Sridharan } \\
(2005)\end{array}$ \\
\hline $\begin{array}{l}\text { Supplier Generative } \\
\text { influence }\end{array}$ & $\begin{array}{l}\text { Adaptation, Networking \& } \\
\text { Interactions }\end{array}$ & $\begin{array}{l}\text { Sousa \& Bradley (2008), } \\
\text { Heylighen (2008). }\end{array}$ \\
\hline Self-Organization & Feedback \& emergence & $\begin{array}{l}\text { Ashby, W. R., (2004), Beijer, et } \\
\text { al. (2012) }\end{array}$ \\
\hline Bid Rigging & $\begin{array}{l}\text { Coóżowicz, K. (2017), Doree, } \\
\text { (2004). }\end{array}$ \\
\hline
\end{tabular}

\section{Validity and Reliability of Instruments}

Reliability analysis of scales in the research instrument (questionnaire) was carried out by performing Cronbach Alpha Coefficient test (Cronbach, 1951). Alpha coefficient of above 0.7 for individual test variables was accepted (Creswell, 2003). Content validity Index was used to test for the validity to ensure that the scale items are meaningful to the sample and capture the issues that are being measured and items were valid as were above 0.7 as indicated in Table 3 below.

Table 3: Results of Content Validity Index and Cronbach Alpha Coefficient

\begin{tabular}{|l|l|c|c|}
\hline Variable & Anchor & $\begin{array}{c}\text { Cronbach Alpha } \\
\text { Value }\end{array}$ & $\begin{array}{c}\text { Content Validity } \\
\text { Index }\end{array}$ \\
\hline Supplier Collaborative Arrangements & Six Point & .834 & .769 \\
\hline Supplier Generative Influence & Six Point & .767 & .800 \\
\hline Self-Organization & Six Point & .700 & .909 \\
\hline Bid Rigging & Six Point & .704 & .714 \\
\hline
\end{tabular}

\section{Data Management and Analysis}

Data analysis was done using the SPSS computer program in order to summarize the data and quick interpretation of results. Quantitative data was generated from the questionnaires through data coding in order to get descriptive statistics in form of frequencies, percentages, mean variance and standard deviations in order to get general responses to the questions. 
European Journal of Logistics, Purchasing and Supply Chain Management

Vol.8 No.1, pp.35-49, March 2020

Published by ECRTD UK

ISSN 2054-0930 (Print), ISSN 2054-0949 (Online)

\section{FINDINGS OF THE STUDY}

\section{Supplier Collaborative Arrangements}

Results indicated a high response rate on supplier collaborative arrangement (average mean $=4.1$ ) among the various units of analysis. Supply collaborative arrangement was dimension in three perspectives namely; information sharing, joint decision making and incentive alignment as indicated here below:

\section{Information Sharing}

A high response rate on the level of information sharing was indicated with an average mean $=$ 4.1. This was attributed to high response rates on the issues of; sharing information on how to prepare bids with other suppliers (Mean $=4.6$ ), sharing information on submitting bids with other suppliers (Mean $=4.3$ ), freely sharing important knowledge that is of interest amongst other suppliers (Mean $=4.0$ ), sharing information on winning tenders with others suppliers (Mean $=3.8$ ), and lastly, telling other suppliers in advance of changes in the supply market (Mean $=3.6$ ),

\section{Joint Decision Making}

Findings indicated a very high response rate on the level of joint decision making (average mean $=4.23$ ), which was due to high responses on the various like; making procurement plans with other suppliers (Mean $=4.7$ ), making joint decision and set joint objectives with other suppliers (Mean $=4.6$ ), providing sales forecasts for the products to other suppliers (Mean $=4.5$ ), jointly developing demand forecasts with other suppliers (Mean $=4.2$ ), and lastly, consulting other suppliers on pricing policy $($ Mean $=4.1)$.

\section{Incentive Alignment}

A moderate response rate on the issue of incentive alignment was observed with an (average mean $=3.8$ ). This was largely due to; frequently sharing losses resulting from relationships with other suppliers (Mean $=4.0$ ), frequently sharing benefits of relationships with other suppliers (Mean $=$ $3.8)$, and lastly, usually having joint investments with other suppliers $($ Mean $=3.6)$

\section{Supplier Generative Influence}

Generally, a very high response rate on supplier generative influence was indicated (average mean $=4.5$ ). Supplier generative influence was dimensioned in three major perspectives, namely; adaptation and networking whose finding are as follows:

\section{Adaptation}

Finding indicated a high response rate on the issue of adaptation (average mean $=4.2$ ). This was due to high responses on the following issues; levels adaptation (average mean $=4.37$ ). acting calmly and set influence that others look at guidance (Mean $=4.8)$, maintaining emotional control and objectivity during emergencies and keep focused (Mean $=4.6$ ), reacting with appropriate urgency in threatening, or emergency situations (Mean $=4.5$ ), taking action to improve work performance deficiencies (Mean $=4.7$ ), demonstrating enthusiasm for learning new approaches 
Vol.8 No.1, pp.35-49, March 2020

Published by ECRTD UK

ISSN 2054-0930 (Print), ISSN 2054-0949 (Online)

for conducting work (Mean $=4.5$ ), always looking for new ways to better achieve organizations objectives (Mean $=4.5$ ), sharing creative ideas on how to solve challenges faced $($ Mean $=4.3)$, adjusting to new work processes and procedures through acquiring new appropriate skills (Mean =4.2), opening and accepting negative and developmental feedback regarding work (Mean $=4.2$ ), using quick and proficient learning new methods of performing work (Mean =4.0), being flexible, open minded and co-operative when dealing with each other (Mean $=4.1)$, participating in trainings to prepare them for unanticipated changes (Mean $=3.9)$, listening to others views and alter their personal views if it's appropriate to do so (Mean $=3.8)$, keeping knowledge and skills current in a rapidly changing environment (Mean $=3.8$ ) and lastly, making decisions based on clear and focused thinking $($ Mean $=3.5)$

\section{Networking}

The study revealed a very high response rate on networking (average mean $=4.6$ ). This was because of; communicating freely with this PDE (Mean $=4.7$ ), giving opportunity to communicate direct to top officials of other suppliers (4.5), suppliers communicating freely with other suppliers $($ Mean $=4.4)$, and lastly, free communication between the company and other supplier's (Mean = 4.3)

\section{Interactions}

A very high response rate on the issue of interactions was revealed (average mean $=4.6$ ). This was attributed to very high response rates on the following; exchanging ideas for long-term problem solving with other suppliers (Mean $=4.8$ ), having a mechanism for evaluating, selecting and pursuing new ideas for innovations (Mean $=4.6$ ), agreeing with other suppliers on ideas and new ways of doing things (Mean =4.6), encouraging suppliers to develop their own ideas and creativity for improvement (Mean = 4.5), enforcing feedback from other suppliers in a positive spirit (4.5), and lastly, communicating during operations with other suppliers (Mean $=4.4$ )

\section{Self-Organization}

Results showed moderate statistics on the aspect of self-organization (average mean $=3.9$ ). Selforganization was dimensioned in two major ways, name; feedback and emergence whose findings are as follows:

\section{Feedback}

Research indicated a fair representation on the issue of feedback (average mean $=3.6$ ), which was largely because of; feeling comfortable about asking fellow suppliers about work performance (Mean = 3.9), informing other suppliers about job performance (Mean = 3.7), interacting with other suppliers (Mean =3.6), when we do not meet deadlines we let other suppliers know (Mean $=3.5$ ), and lastly, informing suppliers about a contract with other suppliers (Mean = 3.2)

\section{Emergence}

Finding revealed high scores on the aspect of emergence (average mean $=4.1$ ). This was due to high responses on the following issues; subcontracting work to other suppliers due to work 
Vol.8 No.1, pp.35-49, March 2020

Published by ECRTD UK

ISSN 2054-0930 (Print), ISSN 2054-0949 (Online)

overloads $($ Mean $=4.3$ ), having high desire to win contacts (Mean $=4.3$ ), encouraging recombination of capabilities (Mean $=4.2$ ), always looking for new ideas in bidding (4.1), tolerating failure in case we do not win bids (Mean $=4.0$ ), and lastly, always trying out new systems in contract management $($ Mean $=3.8)$

\section{Bid Rigging}

A high rate of bid rigging was showed (average mean $=4.3$ ). Bid rigging was dimensioned into three major ways, namely; conspiracy, coordination, and cooperation among suppliers whose results are as follows:

\section{Conspiracy}

Findings indicated very high levels of conspiracy among suppliers (average mean $=4.4$ ), which was largely due to; service provider firms influencing PDE decisions (Mean $=4.8$ ), suppliers subcontracting work to other suppliers (Mean $=4.6$ ), suppliers bidding jointly with other suppliers (Mean $=4.5$ ), certain information on bidding is never disclosed by suppliers during bidding (Mean $=4.2$ ), and lastly, carrying out events only known to us (Mean = 4.1)

\section{Coordination}

Statistics revealed very high scores on the level of coordination among suppliers (average mean $=$ 4.5). This was attributed to very high responses on the following issues; suppliers working with other suppliers to accomplish task (Mean $=4.7)$, suppliers working with other supplier to access more physical resources (Mean $=4.6$ ), suppliers working with other suppliers to plan effectively (Mean = 4.5), suppliers working with other suppliers to achieve economies of scale (Mean = 4.4), and lastly, suppliers working with other suppliers to achieve competence (Mean = 4.2)

\section{Cooperation}

Results showed high responses on the levels of cooperation among suppliers (average mean $=4.1$ ) and this was because of; suppliers working with other suppliers in research and development (Mean = 4.3), suppliers working with other suppliers in purposes of technology $($ Mean $=4.1)$, suppliers working with other suppliers to give PDES better services (Mean $=4.0$ ), suppliers working with other suppliers in better human resources (Mean =4.0), and lastly, suppliers working with other suppliers to win bids (Mean = 3.9)

\section{Correlation Analysis}

The relationships between the study variables were examined using the Pearson (r) correlations coefficient. Only two variables were examined at a time and the resultant Pearson (r) correlations were noted and read off from the table for each pair of variables. 
Vol.8 No.1, pp.35-49, March 2020

Published by ECRTD UK

ISSN 2054-0930 (Print), ISSN 2054-0949 (Online)

Table 4: PDE Relationships

\begin{tabular}{|l|l|l|l|l|l|l|}
\hline & Mean & SD & $\mathbf{1}$ & $\mathbf{2}$ & $\mathbf{3}$ & $\mathbf{4}$ \\
\hline Supplier Collaborative Arrangements & 4.146 & .730 & 1.000 & & & \\
\hline Supplier Generative Influence & 4.462 & .487 & $.302^{* *}$ & 1.000 & & \\
\hline Self-Organization & 3.863 & .409 & $.293^{* *}$ & $.477^{* *}$ & 1.000 & \\
\hline Bid Rigging & 4.259 & .459 & $.415^{* *}$ & $.523^{* *}$ & $.495^{* *}$ & 1.000 \\
\hline **. Correlation is significant at the 0.01 level (2-tailed). & & & & \\
\hline
\end{tabular}

Source: Primary Data (2017)

\section{Supplier Collaborative Arrangements and Bid Rigging}

The results show that supplier collaborative arrangements and bid rigging are significantly and positively related $\left(\mathrm{r}=.415^{* *}, \mathrm{p}<.01\right)$. These results can be partly explained by the fact that when service providers share information about the contract offers from a certain PDE, they tend to agree on certain issues like the prices, subcontracting, this only promotes the undesirable practice of rigging in these transactions. Another observation is that when service providers jointly make decisions such as a move to have only one of the firms submit the bid documents, then the PDE stands to lose out, hence bid rigging.

\section{Supplier Generative Influence and Bid Rigging}

The results show that the supplier generative influence and bid rigging are significantly and positively related $\left(\mathrm{r}=.446^{* *}, \mathrm{p}<.01\right)$. There is free communication amongst service providers for example a service provider is free to consult another service provider on how they will be tendering on the different contracts hence bid rigging. Service providers influence the way other service providers behave and contribute to supply networks. One service provider can hinder another from submitting their bid, which usually leads to bid rigging.

\section{Self-Organization and Bid Rigging}

The results show that self-organization and bid rigging are significantly and positively related $(\mathrm{r}=$ $.386^{* *}, \mathrm{p}<.01$ ). Service providers give each other feedback, for instance, if one is to submit the winning bid, they cover up for him other so as they do not draw attention of the PDE officials. This is one common form of conspiracy among public sector organizations. Service providers can subcontract work to another service provider even without informing PDEs, which indicates bid rigging as well.

\section{Regression Model}

The prediction model helped deduce the degree to which Supplier Collaborative Arrangements, Supplier Generative Influence and Self-organization can explain the extent of Bid Rigging among different PDEs. 
Vol.8 No.1, pp.35-49, March 2020

Published by ECRTD UK

ISSN 2054-0930 (Print), ISSN 2054-0949 (Online)

Table 5: Results from the Regression Analysis

\begin{tabular}{|c|c|c|c|c|c|c|c|}
\hline \multirow[t]{2}{*}{ Model } & \multicolumn{2}{|c|}{$\begin{array}{l}\text { Unstandardized } \\
\text { Coefficients }\end{array}$} & \multirow{2}{*}{$\begin{array}{c}\text { Standar } \\
\text { dized } \\
\text { Coeffici } \\
\text { ents } \\
\text { Beta }\end{array}$} & \multirow[t]{2}{*}{$\mathbf{T}$} & \multirow[t]{2}{*}{ Sig. } & \multicolumn{2}{|c|}{$\begin{array}{c}\text { Collinearity } \\
\text { Statistics }\end{array}$} \\
\hline & $\mathrm{B}$ & $\begin{array}{l}\text { Std. } \\
\text { Error }\end{array}$ & & & & $\begin{array}{c}\text { Tolera } \\
\text { nce }\end{array}$ & VIF \\
\hline (Constant) & 1.245 & .473 & & 2.634 & .010 & & \\
\hline $\begin{array}{l}\text { Supplier Collaborative } \\
\text { Arrangements }\end{array}$ & .160 & .063 & .238 & 2.520 & .014 & .880 & 1.136 \\
\hline $\begin{array}{l}\text { Supplier Generative } \\
\text { Influence }\end{array}$ & .323 & .103 & .321 & 3.119 & .003 & .744 & 1.344 \\
\hline Self-organization & .242 & .091 & .272 & 2.652 & .010 & .748 & 1.336 \\
\hline \multicolumn{8}{|c|}{ Dependent Variable: Bid Rigging } \\
\hline $\mathbf{R}$ & .633 & & & & & & \\
\hline R Square & .401 & & & & & & \\
\hline Adjusted R Square & .378 & & & & & & \\
\hline Std. Error of the Estimate & .386 & & & & & & \\
\hline F Statistic & 16.982 & & & & & & \\
\hline Sig. & .000 & & & & & & \\
\hline
\end{tabular}

Source: Primary Data (2017)

The results showed that the predictors can account for $40.1 \%$ of the variance in Bid Rigging $\mathrm{R}^{2}=$ .401). In order of decreasing capacity to explain Bid Rigging, the predictors were; Supplier Generative Influence $\left(r^{2}=.323\right.$, Sig. $\left.=.003\right)$ which means that it is the highest predictor of bid rigging compared to other variables an increase in supplier generative influence lead to an increase in bid rigging by $32.3 \%$, Self-Organization $\left(\mathrm{r}^{2}=.242\right.$, Sig. $\left.=.010\right)$ is the next predictor of bid rigging that an increase in self-organization leads to an increase in bid rigging by $24.2 \%$, and lastly, Supplier Collaborative Arrangements $\left(\mathrm{r}^{2}=.160\right.$, sig. =.014) which least predicts bid rigging amongst the service providers which means that an increase in supplier collaborative arrangements leads to an increase in bid rigging by $16 \%$. The regression model was statistically significant (sig. $<.01$ ) and thus these findings can be used to draw conclusions and recommendations.

\section{DISCUSSION AND CONCLUSIONS OF THE STUDY}

\section{Discussion of the Findings}

\section{Supplier Collaborative Arrangements and Bid Rigging}

From the analysis there existed a positive significant relationship between supplier collaborative arrangements and bid rigging. This implies that some of these Supplier Collaborative Arrangements involve sharing information about how to win a particular contract, making decisions jointly that leave the PDE with little room for negations for example when they agree amongst each other that only one person should submit the winning bid most cases the winning bid has a very high price but leaves the buyer no option but rather go with that. These findings can 
Vol.8 No.1, pp.35-49, March 2020

Published by ECRTD UK

ISSN 2054-0930 (Print), ISSN 2054-0949 (Online)

be expounded using the scholarly works of Aburto \& Weber, (2007) who noted that suppliers collaborate to share information and resources. This is usually done to achieve better success than when it's done in isolation (Simatupang \& Sridharan, 2002). Potential bidders take on collaboration so as to compete favorably as customers are more demanding hence increasing competition (Ketler, 1997).

\section{Supplier Generative and Bid Rigging}

There is a significant positive relationship between supplier generative influence and bid rigging. Supplier generative influence is the process and or capacity which help people see old things in new ways (Eriksons, E., 1993). Suppliers influence each other to do what they have agreed upon (OECD, 2016). If they agree on who to submit the winning bid then other suppliers must go by that. Therefore in such cases it's noted the best bidder will charge a very high price compared to the next best to qualify. According to Hinchcliffe (1999) supplier generative influence enables suppliers to have consistent changes in their strategies. Influencing is primarily to change ones behavior through persuasion by influencing each other they are able to take decisions that will help them win bids.

\section{Self-Organization and Bid Rigging}

There is a significant positive relationship between self-organizing and bid rigging. This shows that when suppliers are giving feedback to each other there is an indicator that cooperation and coordination exists amongst them. When individuals come together to share ideas they agree on how to execute their duties. It is difficult to predict the behavior of suppliers even if you know their ways to a large extent (Fuchs, et al., 2002). The unpredictable of behavior of suppliers includes for example being hard to know if suppliers worked on a bid jointly or agreed who should submit the winning bid. However although procurement officials cannot easily predict this doesn't mean they don't do it hence the higher chances of bid rigging.

\section{CONCLUSIONS}

Owing to the findings and the discussion that have been raised in this paper, the following conclusions can be raised:

i) From the study, supplier collaborative arrangements are positively related to bid rigging among PDEs. This is a reflection that suppliers share information, take joint decisions and align incentives amongst themselves which eventually promotes bid rigging.

ii) Supplier generative influence highly predicts bid rigging compared to other variables. This means that when suppliers network, interact and adapt they have the power to bid rig and indulge syndicate.

iii) Basing on self-organization, we concluded that, self-organization plays a role on the relationship between supplier collaborative arrangements and supplier generative influence thus leading to bid rigging activities among organizations. 
Vol.8 No.1, pp.35-49, March 2020

Published by ECRTD UK

ISSN 2054-0930 (Print), ISSN 2054-0949 (Online)

\section{Recommendations}

From the study, relevant supplier collaborative arrangements, supplier generative influence and self-organization were taken to be critical for bid rigging among public sector organizations. Therefore, it is recommendable that the following be implemented to reduce bid rigging in Uganda's public procurement system:

i) Supplier collaborative arrangements; procurement officers should listen carefully for any form of sharing information amongst the bidders this is when there is a one on one session with them. Procurement officials should as well design an intelligence system that can detect any kind of collaboration and they should as well require suppliers to declare information of any form of collaboration. Bidders sometimes split profits amongst themselves after they win bids and usually sometimes split contracts amongst themselves therefore procurement officials should monitor service providers even after the award of the contract until it is fully done so they confirm if there was joint working together of service providers. Joint decision making means service providers back up each in terms bidding where need be therefore procurement officers should look out for such irregularities to reduce on bid rigging.

ii) Supplier generative influence; procurement officials in government entities should record all suspicious behavior and statements of those who were involved and those who were around at any stage during the bidding process. They should also have a working understanding of the various laws like PPDA Act and know when and how to apply them in bid rigging. They should be highly informed before choosing criteria for evaluation and awarding tenders. Procurement officials in government entities should have an understanding of the industry structure so as to know which contracts are highly competitive and which are not so as to know where there bargaining power lies.

iii) Self-organization; suppliers always come up with new ways of doing business so as to achieve their organization goals for example joint venturing and subcontracting. PDEs should endeavor to operate in the highness of expertise for example hiring experts to monitor the behavior of suppliers at given stages in the bidding process. Procurement officials should be innovative in their systems, give room for frequent feedback from the suppliers by creating an atmosphere that is open and supportive for whistle blowers. Procurement officers should keenly look out for any loop holes in the system that can easily be manipulated.

\section{References}

Aburto, L., \& Weber, R. (2007). Improved supply chain management based on hybrid demand forecasts. Applied Soft Computing, 7, 136-144.

Ashby, W. R., (2004). Principles of the self-organizing system, E:CO Special Double, Vol. 6 Nos. 1-2, pp. $102-126$

Amanda, C., (2014). Modernization of Public Procurement: Making the Public Market more Competitive and Collusion Proof? Unpublished Master's Thesis, Lunds Universitet, Ekonomihogskolan. 
European Journal of Logistics, Purchasing and Supply Chain Management

Vol.8 No.1, pp.35-49, March 2020

Published by ECRTD UK

ISSN 2054-0930 (Print), ISSN 2054-0949 (Online)

Aubin T, Matheron N, Vielliard JME and Silva M L. (2004), How an Inadequate Acoustic Signal Succeeds in the Extreme Environment of a Tropical Forest? The Song of the White-Browed Warbler, Acta Zoological Sinica (in press).

Bael V., \& Bellis (2017). Bid-rigging and deterrence under EU law, ICN Cartel Workshop, Ottawa, Kris Van Hove

Bajari, P., \& Ye. L., (2001). Competition versus Collusion in Procurement Auctions: Identication \& Testing. February 20, 2001. URL: www-siepr.stanford.edu/workp/swp01001.pdf

Beijer, T.A., Schotanus, F., Telgen, J., Walle, L., (2012). Design of a Supplier Performance Measurement \& Evaluation System for DSM's Petrochemical \& Energy Group, Industrial Engineering \& Management, University of Twente

Creswell, J.W. (2003) Research Design: Qualitative, Quantitative and Mixed Methods Approaches, 2nd ed., Sage, London.

Cronbach LJ (1951). "Coefficient Alpha \& the Internal Structure of Tests". Psychometrika. 16 (3): 297-334

CUT CCIER (2008). Briefing Paper, The Basics of Bid Rigging, CUTS Centre for Competition, Investment \& Economic Regulation, (c) CUTS International, 2008, India

Doree, A. G. (2004). Collusion in the Dutch construction industry: an industrial organization perspective. Building Research \& Information (2004) 32(2), pp. 146-157.

Erikson, E. H. (1993, originally published in 1950). Childhood and society. New York: Norton, 445 pp., $\$ 9.95$

Fuchs, Christian and Schlemm, Annette, The Self-Organization of Society (November 30, 2002). INTAS "Human Strategies in Complexity" Research Paper. Available at SSRN: https://ssrn.com/abstract=385284 or http://dx.doi.org/10.2139/ssrn.385284

Goldstein, J. (2008). Introduction Complexity Science Applied Innovation. The Innovation Journal: The Public Sector Innovation Journal, 13(3), 1-16

Heylighen F. (2008). Complexity and Self-organization, in: Encyclopedia of Library and Information Sciences, eds. M. J. Bates \& M. N. Maack (Taylor \& Francis, 2008)

Hinchcliffe, T. F (1999). A Stuffy of How One Company Uses Organizational Learning to Implement its Strategy. Dissertation Abstract International: Section B: The Sciences and Engineering 60 (3-13), pp. 13-36

Ilango, S. (2014). Nature \& Effects of Bid Rigging in Construction Industry, South Africa: Boroe Inc.

Kauffman, S. (1993). The Origins of Order: Self-Organization and Selection in Evolution,Oxford University Press, New York, NY.

Kettler, H., (2001) Consolidation and Competition in the Pharmaceutical Industry, based on paper delivered at the OHE Conference, London 16 October 2000, Office of Health Economics, London

Kimera H. R., (2006). Competition Regimes in the World: A Civil Society Report, CUTS International, Uganda

Krejcie, R.V., \& Morgan, D.W., (1970). "Determining Sample Size for Research Activities", Educational and Psychological Measurement, 1970, 30, pp. 607-610. 
European Journal of Logistics, Purchasing and Supply Chain Management

Vol.8 No.1, pp.35-49, March 2020

Published by ECRTD UK

ISSN 2054-0930 (Print), ISSN 2054-0949 (Online)

Levy, D. L. (1994). Applications \& Limitations of Complexity Theory in Organization Theory and Strategy. Theory, Application, \& Managerial Implications, Strategic Management Journal , 67.

Mehrjerdi, Y.Z., (2009). The collaborative supply chain, Assembly Automation, Vol. 29, pp. 127 136.

North, C., O'Donnell, E., Marsh, L. (2017). The Economics of Trust In Buyer-Seller Relationships: A Transaction Cost Perspective, Global Journal of Management and Marketing, Vol. 1, No. 1, pp. 81-96

OECD. (2012). Detecting Bid Rigging in Public Procurement. Helping Governments to Obtain Best Value for Money, pp. 4-12.

OECD (2016). Fighting bid rigging in public procurement: Report on implementing the OECD Recommendation, (C) OECD 2016, www.oecd.org/daf/competition

Public Procurement and Disposal of Public Assets [PPDA] Audit Report (2009-2010). Application for Administrative Review by M/s Sinohydro Corporation Limited Procurement of Provider for Design and Build Contract for Strengthening/Rehabilitation of Malaba/ Busia-Bugiri Road Procurement ref no. UNRA/works/2008-09/00001/06, pp 9-10.

Public Procurement and Disposal of Public Assets Act, [PPDA Act] (2003), Acts Supplement to The Uganda Gazette No. 3 Volume XCVII dated 17th January, 2003.

Public Procurement \& Disposal of Public Assets Authority Report [PPDA] (2017); Procurement \& Disposal Audit Report On 74 Entities for Procurements and Disposals for the Year Ended June 2017, Volume III Local Government Entities

Public Procurement and Disposal of Public Assets Act, [PPDA Act] (2014). Statutory Instruments Supplement No. 3 14th February, 2014, The Uganda Gazette No. 9 Volume CVII dated 14th February, 2014, Printed by UPPC, Entebbe, by Order of the Government.

Ring, P.S., \& Van de Ven, A.H., (1994). Developmental Processes of Cooperative Interorganizational Relationships, Academy of Management Journal, 19:90-118.

Różowicz, K., (2017). Bid rigging in public procurement market according to the decisions of the President of the Office of Competition and Consumer Protection, Central and Eastern European Journal of Management and Economics Vol. 5, No.2, 161-176.

Todeva, E., \& Knoke, D. H. (2005). Strategic alliances and models of collaboration, Management Decision, 43(1), 123-148.

Simatupang, T.M. and Sridharan, R. (2004). Benchmarking supply chain collaboration: an empirical study, Benchmarking: An International Journal, Vol. 11, pp. 484-503.

Sousa, C.M.P. \& Bradley, F. (2008). Antecedents of International Pricing Adaptation and Export Performance. Journal of World Business43(3): 307-320

Transparency International (2016). Collusion in Public Procurement Contracts, (C) 2016 Transparency International, European Union

World Bank. (2015). Benchmarking Public Procurement 2015: International Bank for Reconstruction and Development. Corporate Version Inc., pp 1-2. 